\title{
PENINGKATAN KAPASITAS MASYARAKAT DI DAS CITARUM MELALUI PROGRAM
} PARENTING

(Program Pengabdian Kepada Masyarakat di Kampung Babakan Cianjur, Desa

Cihampelas, Kecamatan Cihampelas, Kabupaten Bandung Barat)

\author{
Ansori ${ }^{1}$, Tiffany Estherlita ${ }^{2}$ \\ Program Studi Pendidikan Masyarakat Fakultas Ilmu Pendidkan \\ IKIP Siliwangi Bandung
}

1ansoryalb@ikipsiliwangi.ac.id, 2tiffanyestherlita@gmail.com

\begin{abstract}
ABSTRAK
Program pengabdian masyarakat merupakan kegiatan seluruh mahasiswa Program Studi Pendidikan Masyarakat IKIP SILIWANGI angkatan tahun 2015 menetapkan Bening Saguling Foundation yang berada Daerah Aliran Sungai (DAS) Citarum, Kampung Babakan Cianjur, Desa Cihampelas, Kecamatan Cihampelas, Kabupaten Bandung Barat sebagai tempat pelaksanaan program pengabdian. Berdasarkan hasil identifikasi ditemukan adanya beberapa masalah yang ada di masyarakat seperti tingginya angka putus sekolah dan pernikahan dini. Hal ini berdampak pada minimnya pemahaman akan pola asuh yang tepat dalam mendidik anak. Maka dari itu dilaksanakan sebuah program pemberdayaan perempuan melalui kegiatan parenting dengan tujuan untuk meningkatkan kapasitas masyarakat di DAS Citarum. Metode pelaksanaannya berupa pendekatan pendampingan, pelatihan dan pembinaan melalui kegiatan seminar dengan sasaran program ibu-ibu sekitar. Adapun hasil yang didapatkan adalah meningkatnya pemahaman tentang pola asuh yang tepat dalam mendidik anak.
\end{abstract}

Kata kunci : peningkatan kapasitas mayarakat, DAS Citarum, program parenting

\begin{abstract}
The community service program is a student activity for the Community Education Study Program of SILIWANGI IKIP class of 2015 which establishes the Bening Saguling Foundation which is located in the Citarum River Basin, Babakan Cianjur Village, Cihampelas Village, Cihampelas District, West Bandung Regency as a place of service. Based on the results of the identification found several problems that exist in the community such as high rates of drop out and early marriage. This has an impact on the lack of understanding of appropriate parenting in educating children. Therefore a women's empowerment program was implemented through parenting activities with the aim of increasing the capacity of the community in the Citarum watershed. The method of implementation is in the form of a mentoring approach, training and coaching through seminar activities with the target program of the mothers around. The results obtained are an increase in understanding of appropriate parenting in educating children.
\end{abstract}

Keywords: increasing community capacity, Citarum watershed, parenting program

\section{A. PENDAHULUAN}

Minimnya pemahaman akan makna sesungguhnya dari sebuah pernikahan dan nilai dalam membangun sebuah keluarga yang dialami masyarakat saat ini merupakan 
sebuah masalah yang serius. Dampaknya dapat terlihat dari cukup tingginya angka pernikahan dini, masalah ekonomi keluarga, kesalahan dalam pola asuh menididik anak hingga maraknya kasus perceraian. Menurut data yang diperoleh oleh Badan Pusat Statistik tercatat pernikahan sebanyak 441.813 dan perceraian sebanyak 70.267 di Provinsi Jawa Barat pada tahun 2015. Salah satu faktor yang menyebabkan hal ini terjadi adalah rendahnya tingkat pendidikan masyarakat seperti yang tertera pada data monografi Desa Cihampelas tahun 2017 sebanyak 2.602 orang lulusan SD/sederajat dan 5.650 orang lulusan SMP/Sederajat.

Kesalahan orangtua dalam hal mendidik anak tentunya membawa dampak yang besar bagi perkembangan anak dalam berbagai aspek. Maka dari itu melalui program Parenting dengan menggunakan pendekatan pendidikan mampu menjadi salah satu alternatif untuk meningkatkan kapasitas masyarakat di DAS Citarum dalam hal pendidikan keluarga.

Secara umum yang menjadi landasan hukum tentang program parenting adalah UU Nomor 35 Tahun 2014 tentang perubahan atas UU Nomor 23 Tahun 2002 Tentang Perlindungan Anak menegaskan bahwa setiap anak berhak untuk mendapatkan pendidikan, pemeliharan, perlindungan dan pengasuhan sebagaimana mestinya. Setiap orangtua juga wajib dan bertanggungjawab untuk : a) mengasuh, memelihara, mendidik dan melindungi anak; b) menumbuhkembangkan anak sesuai dengan kemampuan, bakat dan minatnya; c) mencegah terjadinya perkawinan pada usia anak; dan d) memberikan pendidikan karakter dan penanaman nilai budi pekerti pada anak.

Hal ini senada dengan seorang psikologi Tsabary (2016:34) yang mengatakan bahwa setiap anak memiliki kebutuhan untuk diperhatikan, merasa dirinya berharga dan penting bagi keluarganya. Seringkali orangtua hanya berfokus pada pemenuhan kebutuhan fisik anak dan menuntut anak untuk memenuhi target atau harapan yang orangtua tanamkan, sehingga lupa dan mengabaikan kewajibannya untuk memahami diri anak dan memenuhi kebutuhan batinnya.

Program Parenting menjadi sebuah program yang diharapkan mampu meningkatkan kualitas masyarakat. Peningkatan kapasitas keluarga adalah hal dasar dalam proses pembangunan masyarakat. Keluarga yang kuat akan membawa sebuah masyarakat yang kuat dan mampu menjadi tiang yang kokoh bagi sebuah negara. Upaya yang diambil melalui pelaksanaan program parenting ini dapat dilakukan secara berkelanjutkan sesuai dengan kebermanfaatannya. 


\section{B. LANDASAN TEORI}

Darling (1999) menjelaskan bahwa perkembangan dalam kemapuan sosial, kemampuan akademik, perkembangan psikososial dan pembentukan perilaku yang bermasalah adalah pengaruh dari cara orangtua mendidik anak-anaknya. Dengan demikian dapat dijelaskan bahwa proses dan bagaimana cara orangtua mendidik anak dalam sebuah keluarga adalah hal yang sangat penting untuk diperhatikan. Kurangnya pemahaman orangtua akan hal ini dapat menjadi faktor timbulnya masalah-masalah dalam keluarga yang akan berdampak pada masyarakat dan lingkungan sekitar.

Hal ini didukung oleh Jaffe (1998) yang menyatakan bahwa keterlibatan penerimaan diri didasarkan pada presepsi seseorang tentang banyaknya perhatian dan kepekaan orangtua, sikap hangat orangtua, peran yang kuat dan terlibat, peka terhadap kebutuhan anak-anak mereka yang berubah, serta menetapkan standar yang realistis dan aturan yang jelas. Karena itu, orangtua harus memahami betul bagaimana perannya dalam keluarga sehingga mampu terlibat dan mengambil tanggung jawab besar dalam pola pengasuhan dalam proses pendidikan keluarganya.

Cara mendidik anak yang tepat tentunya harus didasari atas kesadaraan orangtua tanpa paksaan dari pihak manapun dan adanya kesepakatan yang diambil oleh kedua belah pihak dalam hal ini suami dan istri. Sebelum menerapkan pola asuh yang tepat, orangtua juga dituntut untuk memahami dirinya sendiri, pasangannya dan anakanaknya.

\section{METODE PELAKSANAAN}

Metode pelaksanaan program parenting yang termasuk dalam rangkaian program Magang 3 ini dilaksanakan sesuai dengan kebutuhan masyarakat DAS Citarum sebanyak 4 kali dalam waktu 3 bulan. Adapun tahapan-tahapan yang terbagi menjadi : (1) tahap perancanaan, (2) tahap pelaksanaan, dan (3) tahap evaluasi. Dalam tahap perencanaan telah ditentukan lokasi kegiatan di Bening Saguling Foundation yang berada di Kampung Babakan Cianjur, Desa Cihampelas, Kecamatan Cihampelas, Kabupaten Bandung Barat dan jenis kegiatan berupa seminar tentang parenting dengan tema pemberdayaan perempuan melalui program parenting. Kemudian tahap pelaksanaan berupa penyajian materi secara teori selama 2 jam oleh mahasiswa peserta program magang 3. Program parenting ini menggunakan metode dalam bentuk seminar melalui ceramah dan tanya jawab. Tahapan pelaksanaan kegiatannya berupa : (1) ceramah 
digunakan untuk menyampaikan materi tentang pengasuhan anak dalam keluarga, (2) tanya jawab gunakan untuk mengetahui dan menemukan solusi dari masalah yang dihadapi oleh keluarga, dan (3) konseling personal dilakukan jika ada orangtua yang butuh penanganan masalah secara lebih mendalam.

Sasaran program parenting ini adalah ibu-ibu disekitar lokasi Bening Saguling Foundation dan orangtua RA dengan rata-rata total peserta 16 orang. Untuk menilai tingkat keberhasilan program ini dilakukan melalui hasil observasi dari proses persiapan, pelaksanaan dan evaluasi dalam hal ini konseling personal yang telah dilakukan, hal ini mampu mememberi gambaran tentang pemahaman dan capaian yang telah diperoleh oleh masing-masing peserta.

\section{HASIL DAN PEMBAHASAN}

\section{Hasil}

Program Magang 3 dilaksanakan oleh mahasiswa yang bersifat wajib sebagai syarat dalam menyeselesaikan studinya. Sebagai mahasiswa pada Program Studi Pendidikan Masyarakat maka ditetapkan bahwa mahasiswa menjadi panitia, fasilitator, observer, konselor dalam proses pelaksanaan program dalam hal ini program parenting.

Berdasarkan hasil observasi dan wawancara yang telah dilakukan, diperoleh gambaran bahwa terjadi perubahan atau peningkatan kapasitas masyarakat di DAS Citarum perihal pengasuhan anak oleh orangtua. Orangtua memahami bagaimana harus menerima dirinya sendiri, pasangan dan anaknya, sehingga mereka mampu memahami atau mengenali dirinya sendiri, pasangan dan anaknya. Orangtua juga menjadi lebih memahami bagaimana menghargai anaknya melalui pola asuh yang tepat dan sesuai dengan anaknya, sehingga orangtua belajar untuk tidak memberikan hukuman fisik dan verbal yang dapat melukai anak tersebut.

Hal positif lainnya adalah adanya perubahan perilaku anak kearah yang lebih baik seperti anak mulai makan dengan baik setelah orangtua berusaha memberikan jenis makanan yang bervariatif dan porsi sesuai untuk anak. Anak yang awalnya kecanduan gadget dan internet mulai bertanggung jawab dikarenakan orangtua mulai memahami dan menerapkan sistem kontrol secara demokratis dan otoritas orangtua sebagai hal yang perlu dilakukan secara konsisten. 


\section{Pembahasan}

Berdasarkan hasil yang didapatkan dalam program parenting maka dapat dikatakan bahwa rangkaian kegiatan ini mendapat respon yang positif dari masyarakat sekitar dan dukungan penuh dari dosen pembimbing dan pengelola Bening Saguling Foundation. Peningkatan kapasitas masyarakat di DAS Citarum melalui program parenting tentunya membawa dampak yang positif bagi pengasuhan anak terutama dalam keluarga muda dengan status pendidikan orangtua yang rendah. Karena setiap materi yang disampaikan adalah materi yang relevan dan aplikatif dalam kehidupan sehari-hari, sehingga mampu menjadi solusi terhadap permaslahan-permasalahan yang dialami.

Melalui program ini setiap orangtua mampu mendukung dan memfasilitasi anakanaknya dalam perkembangan kemampuan sosial, akademik, psikososial dan pembentukan perilaku anak sehingga terhindar dari masalah-masalah anak dan remaja yang serius sesuai dengan pernyataan Darling (1999). Selain itu, orangtua juga mulai belajar untuk memahami bahwa mereka harus mengambil peran dan tanggung jawab dalam pola pengasuhan didalam keluarga, hal ini senada dengan apa yang disampaikan oleh Jaffe (1998).

\section{E. KESIMPULAN}

Berdasarkan hasil dan pembahasan maka dapat disimpulkan bahwa rangkaian program parenting dalam peningkatan kapasitas masyarakat di DAS Citarum merupakan kegiatan yang membawa dampak positif dalam ranah pendidikan keluarga. Masyarakat yang berdaya dapat dimulai dari sebuah keluarga yang kuat. Keluarga yang kuat dihasilkan melalui terjalinnya keharmonisan antar anggota keluarga, saling pengertian dan saling memahami anggota keluarga lainnya dan mendukung apa yang menajadi kewajiban anggota keluarganya. Hal-hal ini akan berdampak pada pola pengasuhan anak-anak dalam keluarga tersebut sehingga setiap keluarga mampu mencetak anak-anak yang berkembang secara baik dalam aspek sosial, akademik, psiokososial dan perilaku.

Program Magang 3 yang dilaksanakan pada Program Studi Masyarakat di IKIP Siliwangi menjadi salah satu cara untuk mahsiswa dapat mengaplikasikan ilmu yang selama ini didapat dalam perkuliahan secara efektif dan efisien melalui programprogram pemberdayaan masyarakat yang relevan dengan kebutuhan masyarakat saat 
ini. Dan mampu menjadi solusi dalam menjawab permasalahan-permasalahan yang ada dalam masyarakat, khususnya dalam program ini yaitu keluarga yang menjadi dasar dalam proses pembangunan dan pemberdayaan masyarakat.

\section{F. DAFTAR PUSTAKA}

Darling, N. (1999). Parenting Style and Its Correlates. ERIC Digest.

Jaffe, M. L. (1998) Adolescence. New York: John Wiley \& Sons, Inc.

Tsabary, S. (Alih Bahasa : Pandam Kuntaswari). 2017. The Awakened Family (Revolusi Dalam Pola Asuh). Jakarta : PT. Gramedia Pustaka Utama.

\section{Akses Internet}

BPS. 2015. Nikah, Talak dan Cerai, serta Rujuk, 2012-2015. [Online]. https://www.bps.go.id/linkTableDinamis/view/id/893, (diakses, 21 November 2018) 